\title{
GMR
}

\section{Development of TRAP primers for Ricinus communis $\mathbf{L}$.}

\author{
K.S. Simões, S.A. Silva, E.L. Machado and H.S. Brasileiro \\ Núcleo de Melhoramento Genético e Biotecnologia, \\ Centro de Ciências Agrárias Ambientais e Biológicas, \\ Universidade Federal do Recôncavo da Bahia, Cruz das Almas, BA, Brasil \\ Corresponding author: K.S. Simões \\ E-mail: karinesimoes01@hotmail.com
}

Genet. Mol. Res. 16 (2): gmr16029647

Received February 16, 2017

Accepted March 16, 2017

Published April 13, 2017

DOI http://dx.doi.org/10.4238/gmr16029647

Copyright (C) 2017 The Authors. This is an open-access article distributed under the terms of the Creative Commons Attribution ShareAlike (CC BY-SA) 4.0 License.

\begin{abstract}
The objective of this article was to develop TRAP (target region amplification polymorphism) primers for castor bean, with the goal of making functional markers available for genetic studies about the species. To do this, oligonucleotides were designed based on ESTs, obtained from the NCBI (National Center for Biotechnology Information) databank, which code enzymes involved in metabolic routes of fatty acid synthesis, ricin synthesis, and resistance to castor bean pathogens. The forward primers were designed with the help of the Primer3 software and, for the reverse, six arbitrary primers were used. To standardize the amplification reactions, the following criteria were used to select the primers: sizes between 18 and $20 \mathrm{bp}$, guanine/ cytosine (GC) in the range of 40 to $60 \%$, and average annealing temperature between $55^{\circ}$ and $62^{\circ} \mathrm{C}$. The design quality of the primers was verified using the Net Primer application. Fifty-six primers were designed, which had an average GC percentage of 53.2\%. A total of 336 combinations were obtained using the 56 fixed and 6 arbitrary primers. Based on polymerase chain reaction, 330 combinations $(89 \%)$ presented good amplification patterns for the genomic DNA of castor
\end{abstract}

Genetics and Molecular Research 16 (2): gmr16029647 
bean. The size of the fragments amplified varied between 50 and 2072 $\mathrm{bp}$. The TRAP primers designed and validated in this study are the first for castor bean and represent a significant increase in the molecular markers for this species.

Key words: GenBank/NCBI; Castor bean; Expressed sequence tag

\section{INTRODUCTION}

Castor bean (Ricinus communis L., $2 \mathrm{n}=2 \mathrm{X}=20$, Euphorbiaceae) is an oleaginous plant with high socioeconomic value because of its industrial and agricultural products and byproducts (Costa et al., 2006), and has been considered as an alternative source for the production of biodiesel. For this reason, it is indispensable to implement strategies to develop genotypes that produce high amounts of oil, are resistant to pathogens, and have low (making it easier for farmers to manage) or high (for chemotherapeutic treatments) concentrations of ricin (Audi et al., 2005). TRAP (target region amplification polymorphism) functional molecular markers are an auxiliary tool important in the process of developing and selecting castor bean genotypes with these characteristics. In addition, these markers can be used in various genetic studies, for example, genetic variability, population genetics, mapping quantitative trait loci (QTLs), associated maps, and assisted selection.

Different types of molecular markers have been used to study the genetic variability of castor bean: amplified fragment length polymorphism (AFLP) (Pecina-Quintero et al., 2013), random amplified DNA polymorphism (RAPD) (Gajera et al., 2010; Silva et al., 2012; Machado et al., 2013; Vivodík et al., 2014, 2015; Lakhani et al., 2015), single nucleotide polymorphism (Foster et al., 2010), simple sequence repeats (SSR) (Bajay et al., 2009, 2011; Seo et al., 2011; Machado and Silva, 2013; Tan et al., 2013, 2014; Gálová et al., 2015; Machado et al., 2016), and inter-simple sequence repeats (ISSR) (Wang et al., 2013; Tomar et al., 2014; Goodarzi et al., 2015; Kallamadi et al., 2015).

The TRAP technique uses bioinformatic tools and EST (expressed sequence tags) data to generate markers from target sequences of candidate genes. The advantages of the technique are high reproducibility, simplicity, access to regions related to genes, and the ability to produce band patterns similar to those using the AFLP technique. The polymorphism is generated from the combination of a fixed primer, designed from an EST of interest, and an arbitrary primer (Hu and Vick, 2003).

TRAP markers were initially developed to sample DNA of the common sunflower (Hu and Vick, 2003). The markers have already been used to study various species, such as lettuce (Lactuca sativa L.; Hu et al., 2005), wheat (Triticum aestivum L.; Liu et al., 2005), the common bean (Phaseolus vulgaris L.; Miklas et al., 2006), fava bean (Vicia faba L.; Kwon et al., 2010), durum wheat (Triticum durum; Al-Doss et al., 2011), and cassava (Manihot esculenta Crantz; Carmo et al., 2015). For castor bean (Ricinus communis L.), there are no reports of the development or use of TRAP markers, although the genome of this species has been sequenced (Chan et al., 2010). Thus, it is necessary to develop and optimize TRAP primers to saturate the genome of castor bean, and therefore, more diverse genetic studies can be conducted, such as genetic variability, markers associated with phenotypic characteristics, and mapping QTLs of populations.

The objectives of the present study were to design TRAP primers for castor bean from ESTs obtained from the National Center for Biotechnology Information (NCBI), and to optimize them using PCR to create functional markers that can be used for genetic studies of this species.

Genetics and Molecular Research 16 (2): gmr16029647 


\section{MATERIAL AND METHODS}

\section{Design of oligonucleotides}

The oligonucleotides were designed using castor bean ESTs involved in metabolic routes of fatty acid synthesis, ricin synthesis, and resistance to pathogens (Table 1).

Table 1. Expressed sequence tags used to develop target region amplification polymorphism (TRAP) primers for castor bean.

\begin{tabular}{|c|c|c|c|}
\hline \multirow[t]{2}{*}{ GenBank No. } & Gene/process & \multirow[t]{2}{*}{ Biological process } & \multirow[t]{2}{*}{ Primer } \\
\hline & Ricin & & \\
\hline RCOM_0792550 & RIP superfamily & Inactivates ribosomes & TRAPRC-01 \\
\hline RCOM_1110780 & RIP superfamily & Inactivates ribosomes & TRAPRC-02 \\
\hline RCOM_1110790 & RIP superfamily & Inactivates ribosomes & TRAPRC-03 \\
\hline RCOM_1180980 & Ricin superfamily & Ricin-type beta-trefoil & TRAPRC-04 \\
\hline RCOM_1960510 & Ricin superfamily & Ricin-type beta-trefoil & TRAPRC-05 \\
\hline RCOM_2105270 & Ricin superfamily & Ricin-type beta-trefoil & TRAPRC-06 \\
\hline RCOM 2159810 & RIP superfamily & Inactivates ribosomes & TRAPRC-07 \\
\hline RCOM_2159910 & RIP superfamily & Inactivates ribosomes & TRAPRC-08 \\
\hline RCOM_2160120 & RIP superfamily & Inactivates ribosomes & TRAPRC-09 \\
\hline RCOM 2160860 & RIP superfamily & Inactivates ribosomes & TRAPRC-10 \\
\hline \multirow{2}{*}{ RCOM_2160530 } & RIP superfamily & Inactivates ribosomes & TRAPRC-11 \\
\hline & Amount of oil & & \\
\hline RCOM 0040840 & LPLAT superfamily & Glycerophospholipid biosynthesis & TRAPRC-12 \\
\hline RCOM 0138550 & Ferritin superfamily & Fatty acid denaturation & TRAPRC-13 \\
\hline RCOM_0251360 & Ferritin superfamily & Fatty acid denaturation & TRAPRC-14 \\
\hline RCOM_0612610 & PLN superfamily & Omega-6 fatty acids denaturation & TRAPRC-15 \\
\hline RCOM_0724080 & PLN2250 superfamily & Lipid phosphate phosphatase & TRAPRC-16 \\
\hline RCOM_ 0853360 & LPLAT superfamily & Glycerophospholipid biosynthesis & TRAPRC-17 \\
\hline RCOM 0893800 & PLA2 subfamily & Phospholipase biosynthesis & TRAPRC-18 \\
\hline RCOM_0900600 & PAP2 superfamily & Encodes protein & TRAPRC-19 \\
\hline RCOM 0925410 & PLN superfamily & Acyl-ACP thioesterase biosynthesis & TRAPRC-20 \\
\hline RCOM_1076810 & Ferritin superfamily & Fatty acid denaturation & TRAPRC-21 \\
\hline RCOM 1081890 & PLN superfamily & Xanthoxin dehydrogenase & TRAPRC-22 \\
\hline RCOM_1403260 & RVT superfamily & Reverse transcriptase & TRAPRC-23 \\
\hline RCOM 1431520 & PLN superfamily & Acetyl-CoA synthesis & TRAPRC-24 \\
\hline RCOM_1464650 & PLN superfamily & Ethanolamine phosphotransferase synthesis & TRAPRC-25 \\
\hline RCOM_1502140 & Oleosin superfamily & Oleosin synthesis & TRAPRC-26 \\
\hline RCOM_1593790 & LPLAT superfamily & Glycerophospholipid synthesis & TRAPRC-27 \\
\hline \multirow[t]{2}{*}{ RCOM_1712710 } & FABZ superfamily & ACP protein synthesis & TRAPRC-28 \\
\hline & Resistance to pathogen & & \\
\hline RCOM_0024370 & Resistance protein RPM1 & Encodes protein RPM1 & TRAPRC-29 \\
\hline RCOM 0464860 & Resistance protein RPP8 & Encodes protein RPP8 & TRAPRC-30 \\
\hline RCOM_0534550 & Resistance protein RGA2 & Encodes protein RGA2 & TRAPRC-31 \\
\hline RCOM 0585390 & Resistance protein RPH8A & Encodes protein RPH8A & TRAPRC-32 \\
\hline RCOM_0585520 & Resistance protein RGA2 & Encodes protein RGA2 & TRAPRC-33 \\
\hline RCOM 0645130 & Resistance protein & Encodes protein kinase & TRAPRC-34 \\
\hline RCOM_0687360 & Resistance protein LRRK2 & Encodes protein LRRK2 & TRAPRC-35 \\
\hline RCOM 0739250 & Resistance protein 4 & Encodes protein 4 & TRAPRC-36 \\
\hline RCOM_0739360 & Resistance protein 23 & Encodes protein 23 & TRAPRC-37 \\
\hline RCOM_0742650 & Resistance protein RPM1 & Encodes protein RPM1 & TRAPRC-38 \\
\hline RCOM_0820400 & Resistance protein RPP8 & Encodes protein RPP8 & TRAPRC-39 \\
\hline RCOM_0898300 & Resistance protein RPS5 & Encodes protein RPS5 & TRAPRC-40 \\
\hline RCOM 0900670 & Resistance protein RGA2 & Encodes protein RGA2 & TRAPRC-41 \\
\hline RCOM_1045150 & Resistance protein TMV & Encodes protein TMV & TRAPRC-42 \\
\hline RCOM 1122050 & Resistance protein RGA3 & Encodes protein RGA3 & TRAPRC-43 \\
\hline RCOM_1184850 & Resistance protein RPP13 & Encodes protein RPP13 & TRAPRC-44 \\
\hline RCOM 1195490 & Resistance protein RPH8A & Encodes protein RPH8A & TRAPRC-45 \\
\hline RCOM_1292200 & Resistance protein RGA2 & Encodes protein RGA2 & TRAPRC-46 \\
\hline RCOM_1329890 & Resistance protein TMV & Encodes protein TMV & TRAPRC-47 \\
\hline RCOM_1330160 & Resistance protein TMV & Encodes protein TMV & TRAPRC-48 \\
\hline RCOM_1397630 & Resistance protein RGA3 & Encodes protein RGA3 & TRAPRC-49 \\
\hline RCOM_1452690 & Resistance protein RGA3 & Encodes protein RGA3 & TRAPRC-50 \\
\hline RCOM_1481570 & Resistance protein 206 & Encodes protein 206 & TRAPRC-51 \\
\hline RCOM_1487620 & Resistance protein RGA3 & Encodes protein RGA3 & TRAPRC-52 \\
\hline RCOM_1508820 & Resistance protein RGA3 & Encodes protein RGA3 & TRAPRC-53 \\
\hline RCOM 1579060 & Resistance protein RGA3 & Encodes protein RGA3 & TRAPRC-54 \\
\hline RCOM_1680500 & Resistance protein RGA3 & Encodes protein RGA3 & TRAPRC-55 \\
\hline RCOM 1689520 & Resistance protein 206 & Encodes protein 206 & TRAPRC-56 \\
\hline
\end{tabular}

Genetics and Molecular Research 16 (2): gmr16029647 
The castor bean ESTs were obtained from the NCBI (National Center for Biotechnology Information, 2016) databank. The forward primers were designed with the help of the Primer3 software (Rozen and Skaletsky, 2000). The forward primers are specific and fixed. For the reverse, six arbitrary primers were used, according to Li and Quiros (2001) and adapted by $\mathrm{Hu}$ and Vick (2003) (Table 2). The arbitrary primers comprise three selective nucleotides at the 3 '-end, four nucleotides rich in adenine/thimine (AT; corresponding to intron regions) or guanine/cytosine (GC; corresponding to exon regions) sequences in the central region, and 11 random nucleotides at the 5 '-end.

Table 2. Arbitrary primers used to validate the TRAP markers for castor bean.

\begin{tabular}{l|l}
\hline Name & Nucleotide sequence $\left(3^{\prime}-5^{\prime}\right)$ \\
\hline Arb1 & GACTGCGTACGAATTGAC \\
\hline Arb2 & GACTGCGTACGAATTTGA \\
\hline Arb3 & GACTGCGTACGAATTGCA \\
\hline Arb4 & GACTGCGTACGAATTAATT \\
\hline Arb5 & GACTGCGTACGAATTTGCC \\
\hline Arb6 & GACTGCGTACGAATTGACC \\
\hline
\end{tabular}

To standardize the PCR, the following criteria were used when selecting the primers: primer size between 18 and $20 \mathrm{bp}$; GC percentage ranging from 40 to $60 \%$; and average annealing temperature between $55^{\circ}$ and $62^{\circ} \mathrm{C}$.

The quality of the design of the primers was verified using the Net Primer application (Premier Biosoft, 2015). The most suitable designs free of clamps, dimers, cross dimers, palindrome sequences, and nucleotide repeats were selected to synthesize the primers. To amplify the genomic DNA of castor bean, the synthesis was made at a scale of $25 \mathrm{nmol}$ (Invitrogen, Carlsbad, CA, USA).

\section{Plant material and DNA extraction}

Genomic DNA was extracted from young, healthy leaves of three elite linages of castor bean developed by the genetic improvement program of Núcleo de Melhoramento Genético e Biotecnologia at Universidade Federal do Recôncavo da Bahia - NBIO/UFRB, in the city of Cruz das Almas, Bahia, Brazil.

Before the extraction, the leaves were disinfected in a solution of $20 \%$ sodium hypochlorite, rinsed with plenty of distilled water and stored in an ultra-freezer at $-80^{\circ} \mathrm{C}$. The DNA was extracted following the protocol described by Doyle and Doyle (1990). For this, approximately $300 \mathrm{mg}$ plant tissue was macerated in a mortar with liquid nitrogen. The macerated material was then transferred to $2-\mathrm{mL}$ microtubes and $700 \mu \mathrm{L}$ extraction buffer was added (2.0\% CTAB, $1.4 \mathrm{M} \mathrm{NaCl}, 0.1 \mathrm{M}$ Tris-HCl, pH 8.0, $20 \mathrm{mM}$ EDTA, 0.4\% 2-mercaptoetanol, $1.0 \% \mathrm{PVP}$ and ultrapure water q.s.p.) at $65^{\circ} \mathrm{C}$. The samples were incubated in a water bath at $65^{\circ} \mathrm{C}$ for $45 \mathrm{~min}$ and homogenized every $15 \mathrm{~min}$. After this, $700 \mu \mathrm{L}$ chloroform: isoamyl alcohol (24:1) was added to the samples. The material was gently homogenized and then centrifuged for $10 \mathrm{~min}$ at 10,000 rpm (using a micro high speed refrigerated centrifuge model VS-15000c). Soon after, the supernatant was collected.

To further purify the material, the extraction step using the chloroform and isoamyl alcohol was repeated. Then, $400 \mu \mathrm{L}$ ice-cold isopropyl alcohol was added to the supernatant, which is equivalent to approximately $2 / 3$ of the volume collected. The samples

Genetics and Molecular Research 16 (2): gmr16029647 
were incubated at $-20^{\circ} \mathrm{C}$ for $20 \mathrm{~min}$ and then centrifuged for $10 \mathrm{~min}$ at $12,000 \mathrm{rpm}$. The precipitate was resuspended in $600 \mu \mathrm{L}$ TE buffer ( $10 \mathrm{mM}$ Tris-HCl, $\mathrm{pH} 8.9,1 \mathrm{mM}$ EDTA), $200 \mu \mathrm{L} 7.5 \mathrm{M}$ ammonium acetate was added, and the solution was incubated on ice for $15 \mathrm{~min}$

After this, the samples were centrifuged for $15 \mathrm{~min}$ at $12,000 \mathrm{rpm}$. The supernatant was recovered by adding $800 \mu \mathrm{L}$ absolute ethanol. The samples were then incubated for $1 \mathrm{~h}$ at $-20^{\circ} \mathrm{C}$ and centrifuged for $10 \mathrm{~min}$ at $12,000 \mathrm{rpm}$. The precipitate was washed with $500 \mu \mathrm{L}$ $70 \%$ ethanol (v/v), centrifuged for $5 \mathrm{~min}$ at $12,000 \mathrm{rpm}$ and dried at room temperature. It was then resuspended in TE buffer containing $1 \mu \mathrm{L}$ RNAse $(10 \mathrm{mg} / \mathrm{mL})$ and the samples were incubated in a water bath at $37^{\circ} \mathrm{C}$ for $1 \mathrm{~h}$. Subsequently, the samples were stored in a freezer at $-20^{\circ} \mathrm{C}$ until they were used.

\section{Quantification of the genomic DNA}

To evaluate the quality and quantity of the extracted DNA, a total of $3 \mu \mathrm{L}$ DNA was added to $5 \mu \mathrm{L}$ dye solution ( $30 \%$ glycerol and $0.25 \%$ bromophenol blue). The samples were then applied to $0.8 \%$ agarose gel, stained with ethidium bromide $(0.5 \mathrm{mg} / \mathrm{mL})$, and electrophoresed for approximately $1 \mathrm{~h}$ and $20 \mathrm{~min}$ at $80 \mathrm{~V}$. The quantity of DNA was evaluated using a comparative analysis with a known concentration of DNA (lambda DNA, Invitrogen, USA). To carry out the amplification reactions, the samples were diluted in TE buffer to adjust the concentration to $5 \mathrm{ng} / \mu \mathrm{L}$.

\section{Optimization of the PCRs for the TRAP primers}

The amplification reactions were optimized to a final volume of $15 \mu \mathrm{L}$ containing a $1 \mathrm{X}$ buffer (50 mM Tris-HCl, $20 \mathrm{mM} \mathrm{KCl}$ ), 1.0 U Taq DNA Polymerase (Invitrogen, Brazil), $2.0 \mathrm{mM} \mathrm{MgCl}, 0.2 \mathrm{mM}$ dNTP (Invitrogen, Brazil), $0.2 \mu \mathrm{M}$ primers (IDT) and $10 \mathrm{ng}$ DNA.

The amplifications were made using the following program: $94^{\circ} \mathrm{C}$ for $2 \mathrm{~min} ; 5$ cycles at $94^{\circ} \mathrm{C}$ for $45 \mathrm{~s}, 35^{\circ} \mathrm{C}$ for $45 \mathrm{~s}$, and $72^{\circ} \mathrm{C}$ for $1 \mathrm{~min}$; followed by 30 cycles at $94^{\circ} \mathrm{C}$ for $45 \mathrm{~s}$, $40^{\circ} \mathrm{C}$ for $45 \mathrm{~s}, 72^{\circ} \mathrm{C}$ for $1 \mathrm{~min}$, and a final extension at $72^{\circ} \mathrm{C}$ for $7 \mathrm{~min}$ (Carmo et al., 2015). This was done in a thermocycler, model Veriti ${ }^{\circledR}$ 96-well (Applied Biosystems). Electrophoresis was performed on $4 \%$ agarose gel stained with ethidium bromide $(0.5 \mathrm{mg} / \mathrm{mL})$. The amplified products were viewed using a transilluminator and photographed using the Kodak Science digital software. The size of the fragments was estimated by visual comparison with a 100-bp ladder (Invitrogen, Brazil).

\section{RESULTS AND DISCUSSION}

\section{Selecting the TRAP combinations}

A total of 56 TRAP primers were developed for castor bean, which are denominated by the abbreviations TRAPRC followed by numbers (Table 3 ). The primers have an average GC percentage of $53.20 \%$ (Table 3). This result is close to what was found by Bajay et al. (2009), who reported $47.56 \%$ for 41 pairs of SSR primers for caster bean, and Machado and Silva (2013), who found an average GC percentage of $47.29 \%$ for 30 pairs of SSR primers for the same species.

Genetics and Molecular Research 16 (2): gmr16029647 
Table 3. Fixed target region amplification polymorphism (TRAP) primers developed for castor bean.

\begin{tabular}{|c|c|c|}
\hline Primer & Sequence $\left(5^{\prime}-3^{\prime}\right)$ & $\mathrm{GC} \%$ \\
\hline TRAPRC-01 & CCACATCCAGCACCTTTTG & 52.63 \\
\hline TRAPRC-02 & TGTGGAGCGTTGAGGATTC & 52.63 \\
\hline TRAPRC-03 & TGCTCGCAGGCAAAGATAC & 52.63 \\
\hline TRAPRC-04 & TGTCCCATATTTGCCAACG & 47.37 \\
\hline TRAPRC-05 & TGACGACTGCTCCTTCCAC & 57.89 \\
\hline TRAPRC-06 & GACGACTGCTCCTTCCACA & 57.89 \\
\hline TRAPRC-07 & TACGCACTATGGGCTCAGG & 57.89 \\
\hline TRAPRC-08 & CCCTGATGTCGCTGCTAAA & 52.63 \\
\hline TRAPRC-09 & AACCGCAAGTGGTCAAACA & 47.37 \\
\hline TRAPRC-10 & CGGGTGGCATCAGTTACAG & 57.89 \\
\hline TRAPRC-11 & GGCGGATGCTATCTGTGAA & 52.63 \\
\hline TRAPRC-12 & GACACCTTTGTTGCCATCG & 52.63 \\
\hline TRAPRC-13 & ATCCCCAACAAGCACAACA & 47.37 \\
\hline TRAPRC-14 & TTTCCTTGCTGCCTCTGTG & 52.63 \\
\hline TRAPRC-15 & CCGTGATTCTGGTGGTGAG & 57.89 \\
\hline TRAPRC-16 & TTACAACTGCGGCATCTCC & 52.63 \\
\hline TRAPRC-17 & TCCATCCCTTTCCATCCTC & 52.63 \\
\hline TRAPRC-18 & TGGCATTTGCTTCCTTTGA & 42.11 \\
\hline TRAPRC-19 & AATGCCAGCACCTACACCA & 52.63 \\
\hline TRAPRC-20 & TTATCTTGGGAGGGGCTTG & 52.63 \\
\hline TRAPRC-21 & ATCCTTCCAGGCAATCCAC & 52.63 \\
\hline TRAPRC-22 & CACTCGCCTGTTCAGCACT & 57.89 \\
\hline TRAPRC-23 & AGCAAGCCGCACCTAAGAT & 52.63 \\
\hline TRAPRC-24 & GTCCAAGCAAAAGCCACCT & 52.63 \\
\hline TRAPRC-25 & CCACCAATCCAACGCATAG & 52.63 \\
\hline TRAPRC-26 & TTCATCTCCCTTGCCTTCC & 52.63 \\
\hline TRAPRC-27 & CGAAATCCTCCTGCTCCTC & 52.63 \\
\hline TRAPRC-28 & GCCACCATCTTCACCACAG & 57.89 \\
\hline TRAPRC-29 & ACAGCGTTCAGCAGTCACC & 57.89 \\
\hline TRAPRC-30 & CTTCTCAGTTGCCCGTTCA & 52.63 \\
\hline TRAPRC-31 & CCACCAATGAACCAACTGC & 52.63 \\
\hline TRAPRC-32 & TGCCGACTTCTCCTTTCCT & 52.63 \\
\hline TRAPRC-33 & CAGTCACAATCGCCAAAGG & 52.63 \\
\hline TRAPRC-34 & TGGGCATTTTCTTGGTTGA & 42.11 \\
\hline TRAPRC-35 & CCTCATCATCGTTGCTGCT & 52.63 \\
\hline TRAPRC-36 & TCCCTCCAACAACAGCAAG & 52.63 \\
\hline TRAPRC-37 & GCTCACGCACTGGACTCAT & 57.89 \\
\hline TRAPRC-38 & CAAACTCCTCTGCCATCCA & 52.63 \\
\hline TRAPRC-39 & GCACCCGAAATCTTCCACT & 52.63 \\
\hline TRAPRC-40 & CCACTCAACACCGTTCCAC & 57.89 \\
\hline TRAPRC-41 & AGGATGTTGTCGCTCACCA & 52.63 \\
\hline TRAPRC-42 & TTTGGGCAACAAGCAAGAG & 47.37 \\
\hline TRAPRC-43 & ATGCCAAGAACCCCAAGAC & 52.63 \\
\hline TRAPRC-44 & CGTCCACCCACACTTTCAC & 57.89 \\
\hline TRAPRC-45 & TTCGCTGGATGGATAGTCG & 52.63 \\
\hline TRAPRC-46 & CCAGTCACCGTTTGTTGCT & 52.63 \\
\hline TRAPRC-47 & CGCCTCTGACAAATCTGGA & 52.63 \\
\hline TRAPRC-48 & GGCTAAGGCTTCCAACTGC & 57.89 \\
\hline TRAPRC-49 & TCCTGTCCAATGCTGAACC & 52.63 \\
\hline TRAPRC-50 & ATTCCACCCTCCAGTTTGC & 52.63 \\
\hline TRAPRC-51 & CCACCGAGAGAGCATACCA & 57.89 \\
\hline TRAPRC-52 & GTGGCAAATGCTCACAGGT & 52.63 \\
\hline TRAPRC-53 & TACAACTTCGGGTGGTGGA & 52.63 \\
\hline TRAPRC-54 & ATCCTTTTCCGTCGCAGTC & 52.63 \\
\hline TRAPRC-55 & TGATGGAAACCCTTGTGGA & 47.37 \\
\hline TRAPRC-56 & CTTGTGCCCTACCAACTGC & 57.89 \\
\hline
\end{tabular}

With the 56 fixed primers developed, it was possible to make 336 combinations using 6 arbitrary primers, and 330 combinations $(89 \%)$ presented an adequate amplification pattern for the three linages analyzed (Figure 1). Low percentage of combinations of fixed and arbitrary primers was found by Carmo et al. (2015) when developing TRAP markers for cassava. These authors made 396 combinations, of which 253 (64\%) had a good amplification pattern.

Genetics and Molecular Research 16 (2): gmr16029647 


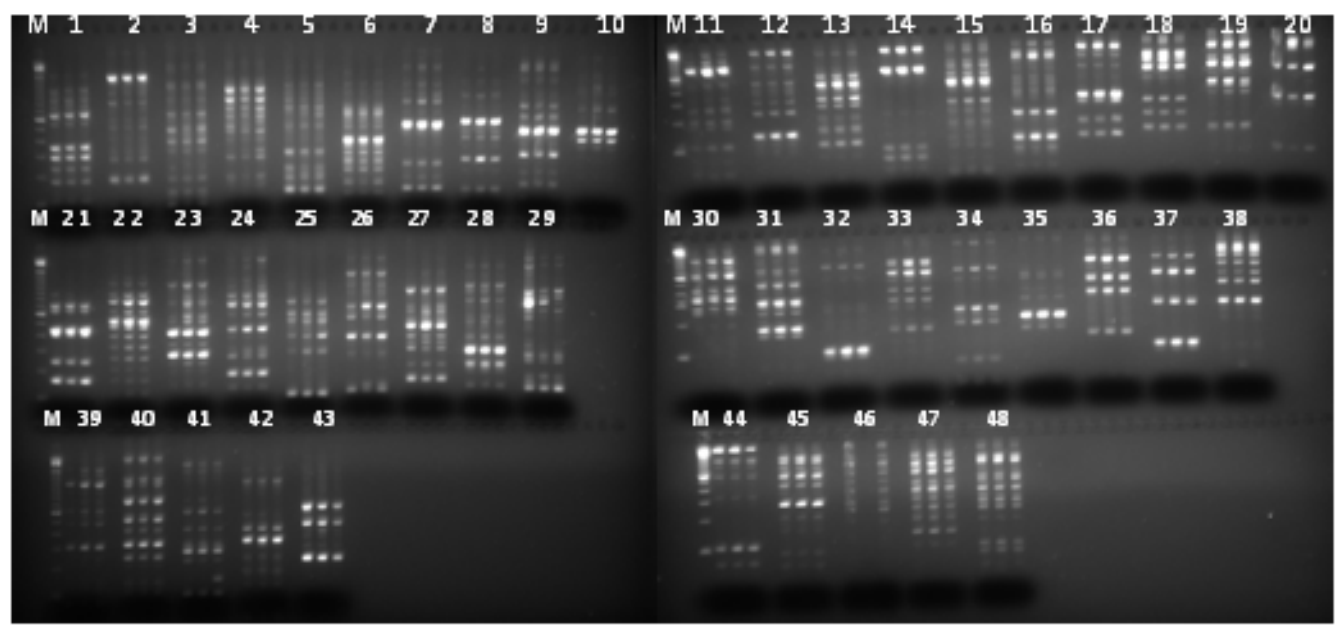

Figure 1. Electrophoretic profile, on $4 \%$ agarose gel, obtained after amplifying the genomic DNA of three lineages of Ricinus communis L. using target region amplification polymorphism (TRAP) primers. Lane M: 100bp molecular weight marker. And the combinations: Lane 1- TRAPC22+ARB1, lane 2- TRAPC22+ARB2, lane 3- TRAPC22+ARB3, lane 4- TRAPC22+ARB4, lane 5- TRAPC22+ARB5, lane 6- TRAPC22+ARB6, lane 7TRAPC23+ARB1, lane 8- TRAPC23+ARB2, lane 9- TRAPC23+ARB3, lane 10- TRAPC23+ARB4, lane 11TRAPC23+ARB5, lane 12- TRAPC23+ARB6, lane 13- TRAPC24+ARB1, lane 14- TRAPC24+ARB2, lane 15- TRAPC24+ARB3, lane 16- TRAPC24+ARB4, lane 17- TRAPC24+ARB5, lane 18- TRAPC24+ARB6, lane 19- TRAPC25+ARB1, lane 20- TRAPC25+ARB2, lane 21- TRAPC25+ARB3, lane 22- TRAPC25+ARB4, lane 23- TRAPC25+ARB5, lane 24- TRAPC225+ARB6. lane 25- TRAPC46+ARB1, lane 26- TRAPC46+ARB2, lane 27- TRAPC46+ARB3, lane 28- TRAPC46+ARB4, lane 29- TRAPC46+ARB5, lane 30- TRAPC46+ARB6, lane 31- TRAPC47+ARB1, lane 32- TRAPC47+ARB2, lane 33- TRAPC47+ARB3, lane 34- TRAPC47+ARB4, lane 35- TRAPC47+ARB5, lane 36- TRAPC47+ARB6, lane 37- TRAPC48+ARB1, lane 38- TRAPC48+ARB2, lane 39- TRAPC48+ARB3, lane 40- TRAPC48+ARB4, lane 41- TRAPC48+ARB5, lane 42- TRAPC48+ARB6, lane 43- TRAPC49+ARB1, lane 44- TRAPC49+ARB2, lane 45- TRAPC49+ARB3, lane 46- TRAPC49+ARB4, lane 47- TRAPC49+ARB5, and lane 48- TRAPC49+ARB6.

Different percentages of combinations with fixed and arbitrary primers have been obtained for different species of plants. Luo et al. (2015) developed 91 combinations of TRAP primers (13 fixed and 7 arbitrary) for mango, of which $72.5 \%$ were consistent, and Kumar et al. (2014) reported 262 TRAP combinations for chickpea, of which $42 \%$ of the markers were valid. Similar combination percentage of fixed and arbitrary TRAP primers $(49 \%)$ was found by Zhang et al. (2012) for the ornamental species Paeonia suffruticosa.

In the present study, the number of amplified loci, for the 330 combinations of the primers, varied from 2 (TRAP5 +ARB1; TRAP5 +ARB3; TRAP6+ARB3; TRAP14+ARB3; TRAP17+ARB4; TRAP20+ARB2; TRAP30+ARB1; TRAP30+ARB2; TRAP34+ARB3) to 15 (TRAP22+ARB6), with an average of 1.22 loci per combination (Table 4).

The size of the products amplified varied from 50 to $2072 \mathrm{bp}$. The combinations TRAP46+ARB4, TRAP46+ARB5, TRAP46+ARB6, TRAP49+ARB1，TRAP49+ARB2, TRAP51+ARB6, and TRAP52+ARB1 amplified fragments with $50 \mathrm{bp}$; the remaining amplified fragments with sizes above this value (Table 4). 
Table 4. Number of amplified loci for the target region amplification polymorphism (TRAP) combinations (fixed and arbitrary primers).

\begin{tabular}{|c|c|c|c|c|c|}
\hline Primers & Number of loci & Size of loci (bp) & Primers & Number of loci & Size of loci (bp) \\
\hline TRAP1+ARB1 & 9 & $97-1100$ & TRAP8+ARB1 & 3 & $80-1300$ \\
\hline TRAP1+ARB2 & 12 & $100-720$ & TRAP8+ARB2 & 6 & $80-1470$ \\
\hline TRAP1+ARB3 & 6 & $96-800$ & TRAP8+ARB3 & 8 & $85-1340$ \\
\hline TRAP1+ARB4 & 6 & $91-500$ & TRAP8+ARB4 & 4 & $200-1540$ \\
\hline TRAP1+ARB5 & 12 & $95-1500$ & TRAP8+ARB5 & 7 & $120-1760$ \\
\hline TRAP1+ARB6 & 13 & $90-1100$ & TRAP8+ARB6 & 7 & $100-1290$ \\
\hline TRAP2+ARB1 & 9 & $113-2072$ & TRAP9+ARB1 & 3 & $100-700$ \\
\hline TRAP2+ARB2 & 6 & $180-955$ & TRAP9+ARB2 & 5 & $160-2000$ \\
\hline TRAP2+ARB3 & 10 & $90-1180$ & TRAP9+ARB3 & 5 & $205-1300$ \\
\hline TRAP2+ARB4 & 9 & $190-1675$ & TRAP9+ARB4 & 4 & $590-2000$ \\
\hline TRAP2+ARB5 & 9 & $177-1500$ & TRAP9+ARB5 & 4 & $205-1400$ \\
\hline TRAP2+ARB6 & 8 & $113-1200$ & TRAP9+ARB6 & 5 & $220-1400$ \\
\hline TRAP3+ARB1 & 6 & $115-2000$ & TRAP10+ARB1 & 8 & $113-1900$ \\
\hline TRAP3+ARB2 & 12 & $105-1660$ & TRAP10+ARB2 & 6 & $86-1780$ \\
\hline TRAP3+ARB3 & 12 & $90-1700$ & TRAP10+ARB3 & 10 & $86-1530$ \\
\hline TRAP3+ARB4 & 7 & $120-1100$ & TRAP10+ARB4 & 5 & $87-2072$ \\
\hline TRAP3+ARB5 & 9 & $100-1600$ & TRAP10+ARB5 & 8 & $87-2000$ \\
\hline TRAP3+ARB6 & 9 & $90-2072$ & TRAP10+ARB6 & 6 & $88-1100$ \\
\hline TRAP4+ARB1 & 7 & $120-1800$ & TRAP11+ARB1 & 6 & $87-1800$ \\
\hline TRAP4+ARB2 & 5 & $90-1400$ & TRAP11+ARB2 & 9 & $87-2025$ \\
\hline TRAP4+ARB3 & 8 & $102-1400$ & TRAP11+ARB3 & 8 & $87-1060$ \\
\hline TRAP4+ARB4 & 8 & $120-1500$ & TRAP11+ARB4 & 7 & $92-1400$ \\
\hline TRAP4+ARB5 & 4 & $300-1100$ & TRAP11+ARB5 & 9 & $110-950$ \\
\hline TRAP4+ARB6 & 9 & $200-1500$ & TRAP11+ARB6 & 7 & $110-930$ \\
\hline TRAP5+ARB1 & 2 & $280-2000$ & TRAP12+ARB1 & 6 & $212-2045$ \\
\hline TRAP5+ARB2 & 3 & $130-1200$ & TRAP12+ARB2 & 7 & $97-1700$ \\
\hline TRAP5+ARB3 & 2 & $150-600$ & TRAP12+ARB3 & 4 & $86-2000$ \\
\hline TRAP5+ARB4 & 6 & $130-1200$ & TRAP12+ARB4 & 4 & $107-1500$ \\
\hline TRAP5+ARB5 & 6 & $250-1700$ & TRAP12+ARB5 & 9 & $87-1420$ \\
\hline TRAP5+ARB6 & 7 & $120-2000$ & TRAP12+ARB6 & 9 & $87-1200$ \\
\hline TRAP6+ARB1 & 4 & $100-1100$ & TRAP13+ARB1 & 0 & 0 \\
\hline TRAP6+ARB2 & 4 & $190-1460$ & TRAP13+ARB2 & 0 & 0 \\
\hline TRAP6+ARB3 & 2 & $86-1300$ & TRAP13+ARB3 & 0 & 0 \\
\hline TRAP6+ARB4 & 4 & $240-800$ & TRAP13+ARB4 & 0 & 0 \\
\hline TRAP6+ARB5 & 4 & $200-1200$ & TRAP13+ARB5 & 0 & 0 \\
\hline TRAP6+ARB6 & 6 & $240-1050$ & TRAP13+ARB6 & 0 & 0 \\
\hline TRAP7+ARB1 & 5 & $210-1150$ & TRAP14+ARB1 & 4 & $95-1000$ \\
\hline TRAP7+ARB2 & 5 & $280-2072$ & TRAP14+ARB2 & 7 & $164-770$ \\
\hline TRAP7+ARB3 & 6 & $94-1900$ & TRAP14+ARB3 & 2 & $100-700$ \\
\hline TRAP7+ARB4 & 4 & $450-1900$ & TRAP14+ARB4 & 3 & $90-1330$ \\
\hline TRAP7+ARB5 & 5 & $115-1500$ & TRAP14+ARB5 & 4 & $97-780$ \\
\hline TRAP7+ARB6 & 7 & $90-1060$ & TRAP14+ARB6 & 8 & $110-830$ \\
\hline TRAP15+ARB1 & 10 & $90-1360$ & TRAP22+ARB1 & 10 & $95-1540$ \\
\hline TRAP15+ARB2 & 7 & $105-1660$ & TRAP22+ARB2 & 14 & $95-1430$ \\
\hline TRAP15+ARB3 & 10 & $90-2045$ & TRAP22+ARB3 & 14 & $103-1630$ \\
\hline TRAP15+ARB4 & 9 & $107-2000$ & TRAP22+ARB4 & 13 & $120-1900$ \\
\hline TRAP15+ARB5 & 13 & $90-1600$ & TRAP22+ARB5 & 12 & $108-2072$ \\
\hline TRAP15+ARB6 & 6 & $90-900$ & TRAP22+ARB6 & 15 & $107-1600$ \\
\hline TRAP16+ARB1 & 8 & $100-865$ & TRAP23+ARB1 & 11 & $110-1550$ \\
\hline TRAP16+ARB2 & 9 & $95-954$ & TRAP23+ARB2 & 9 & $110-1560$ \\
\hline TRAP16+ARB3 & 8 & $90-1640$ & TRAP23+ARB3 & 10 & $114-1700$ \\
\hline TRAP16+ARB4 & 8 & $110-1585$ & TRAP23+ARB4 & 6 & $300-1290$ \\
\hline TRAP16+ARB5 & 6 & $95-1430$ & TRAP23+ARB5 & 7 & $113-785$ \\
\hline TRAP16+ARB6 & 6 & $95-2072$ & TRAP23+ARB6 & 10 & $105-1270$ \\
\hline TRAP17+ARB1 & 8 & $105-1650$ & TRAP24+ARB1 & 12 & $108-1560$ \\
\hline TRAP17+ARB2 & 7 & $120-1370$ & TRAP24+ARB2 & 13 & $104-1830$ \\
\hline TRAP17+ARB3 & 5 & $190-1590$ & TRAP24+ARB3 & 7 & $102-760$ \\
\hline TRAP17+ARB4 & 2 & $195-1690$ & TRAP24+ARB4 & 10 & $104-1420$ \\
\hline TRAP17+ARB5 & 7 & $95-1730$ & TRAP24+ARB5 & 10 & $110-1360$ \\
\hline TRAP17+ARB6 & 6 & $92-1480$ & TRAP24+ARB6 & 10 & $107-1740$ \\
\hline TRAP18+ARB1 & 5 & $230-1350$ & TRAP25+ARB1 & 11 & $103-2000$ \\
\hline TRAP18+ARB2 & 7 & $107-1300$ & TRAP25+ARB2 & 8 & $100-1400$ \\
\hline TRAP18+ARB3 & 6 & $92-750$ & TRAP25+ARB3 & 10 & $104-1530$ \\
\hline TRAP18+ARB4 & 4 & $400-2000$ & TRAP25+ARB4 & 8 & $105-1600$ \\
\hline TRAP18+ARB5 & 7 & $113-900$ & TRAP25+ARB5 & 8 & $108-1300$ \\
\hline
\end{tabular}

Continued on next page

Genetics and Molecular Research 16 (2): gmr16029647 
Development of TRAP primers for Ricinus communis L.

\begin{tabular}{|c|c|c|c|c|c|}
\hline Primers & Number of loci & Size of loci (bp) & Primers & Number of loci & Size of loci (bp) \\
\hline TRAP18+ARB6 & 7 & $117-864$ & TRAP25+ARB6 & 8 & $220-590$ \\
\hline TRAP19+ARB1 & 11 & $117-1800$ & TRAP26+ARB1 & 4 & $106-830$ \\
\hline TRAP19+ARB2 & 8 & $110-1630$ & TRAP26+ARB2 & 7 & $100-1600$ \\
\hline TRAP19+ARB3 & 8 & $86-1500$ & TRAP26+ARB3 & 9 & $108-1550$ \\
\hline TRAP19+ARB4 & 8 & $86-1330$ & TRAP26+ARB4 & 7 & $207-1500$ \\
\hline TRAP19+ARB5 & 9 & $91-1530$ & TRAP26+ARB5 & 8 & $123-1700$ \\
\hline TRAP19+ARB6 & 12 & $91-1775$ & TRAP26+ARB6 & 6 & $106-952$ \\
\hline TRAP20+ARB1 & 7 & $95-1400$ & TRAP27+ARB1 & 12 & $112-1300$ \\
\hline TRAP20+ARB2 & 2 & $325-620$ & TRAP27+ARB2 & 10 & $122-1250$ \\
\hline TRAP20+ARB3 & 6 & $93-600$ & TRAP27+ARB3 & 10 & $107-1430$ \\
\hline TRAP20+ARB4 & 4 & $206-1800$ & TRAP27+ARB4 & 6 & $120-1400$ \\
\hline TRAP20+ARB5 & 7 & $103-1100$ & TRAP27+ARB5 & 6 & $106-820$ \\
\hline TRAP20+ARB6 & 3 & $170-545$ & TRAP27+ARB6 & 6 & $112-900$ \\
\hline TRAP21+ARB1 & 8 & $174-1150$ & TRAP28+ARB1 & 8 & $108-1340$ \\
\hline TRAP21+ARB2 & 7 & $110-990$ & TRAP28+ARB2 & 8 & $123-1360$ \\
\hline TRAP21+ARB3 & 6 & $120-1360$ & TRAP28+ARB3 & 9 & $118-1600$ \\
\hline TRAP21+ARB4 & 6 & $200-1445$ & TRAP28+ARB4 & 10 & $117-1600$ \\
\hline TRAP21+ARB5 & 9 & $120-1200$ & TRAP28+ARB5 & 10 & $95-2072$ \\
\hline TRAP21+ARB6 & 8 & $114-815$ & TRAP28+ARB6 & 8 & $114-1500$ \\
\hline TRAP29+ARB1 & 7 & $100-1500$ & TRAP36+ARB1 & 7 & $170-1500$ \\
\hline TRAP29+ARB2 & 6 & $110-1260$ & TRAP36+ARB2 & 8 & $120-2072$ \\
\hline TRAP29+ARB3 & 4 & $107-1300$ & TRAP36+ARB3 & 7 & $120-1200$ \\
\hline TRAP29+ARB4 & 7 & $116-1200$ & TRAP36+ARB4 & 6 & $480-1800$ \\
\hline TRAP29+ARB5 & 7 & $107-1370$ & TRAP36+ARB5 & 8 & $130-800$ \\
\hline TRAP29+ARB6 & 8 & $109-1100$ & TRAP36+ARB6 & 9 & $170-1600$ \\
\hline TRAP30+ARB1 & 2 & $320-500$ & TRAP37+ARB1 & 8 & $140-1400$ \\
\hline TRAP30+ARB2 & 2 & $216-1400$ & TRAP37+ARB2 & 9 & $110-1600$ \\
\hline TRAP30+ARB3 & 10 & $110-1400$ & TRAP37+ARB3 & 6 & $100-600$ \\
\hline TRAP30+ARB4 & 10 & $120-1530$ & TRAP37+ARB4 & 6 & $200-1500$ \\
\hline TRAP30+ARB5 & 9 & $120-1700$ & TRAP37+ARB5 & 7 & $140-1500$ \\
\hline TRAP30+ARB6 & 10 & $114-1800$ & TRAP37+ARB6 & 11 & $140-2000$ \\
\hline TRAP31+ARB1 & 9 & $106-1300$ & TRAP38+ARB1 & 5 & $200-850$ \\
\hline TRAP31+ARB2 & 11 & $110-1300$ & TRAP38+ARB2 & 5 & $200-1000$ \\
\hline TRAP31+ARB3 & 10 & $107-1020$ & TRAP38+ARB3 & 8 & $180-1500$ \\
\hline TRAP31+ARB4 & 8 & $112-1470$ & TRAP38+ARB4 & 8 & $130-800$ \\
\hline TRAP31+ARB5 & 8 & $108-1440$ & TRAP38+ARB5 & 7 & $120-1200$ \\
\hline TRAP31+ARB6 & 8 & $108-980$ & TRAP38+ARB6 & 7 & $130-1400$ \\
\hline TRAP32+ARB1 & 8 & $105-1500$ & TRAP39+ARB1 & 7 & $180-1400$ \\
\hline TRAP32+ARB2 & 11 & $109-1600$ & TRAP39+ARB2 & 9 & $160-2072$ \\
\hline TRAP32+ARB3 & 7 & $112-1200$ & TRAP39+ARB3 & 9 & $170-1600$ \\
\hline TRAP32+ARB4 & 8 & $109-1700$ & TRAP39+ARB4 & 5 & $180-1100$ \\
\hline TRAP32+ARB5 & 9 & $113-1400$ & TRAP39+ARB5 & 10 & $150-1200$ \\
\hline TRAP32+ARB6 & 9 & $103-1000$ & TRAP39+ARB6 & 3 & $160-1300$ \\
\hline TRAP33+ARB1 & 8 & $230-1500$ & TRAP40+ARB1 & 8 & $130-1000$ \\
\hline TRAP33+ARB2 & 8 & $110-1850$ & TRAP40+ARB2 & 5 & $90-1600$ \\
\hline TRAP33+ARB3 & 7 & $105-1560$ & TRAP40+ARB3 & 5 & $300-1400$ \\
\hline TRAP33+ARB4 & 5 & $110-1560$ & TRAP40+ARB4 & 7 & $210-700$ \\
\hline TRAP33+ARB5 & 9 & $108-1400$ & TRAP40+ARB5 & 8 & $280-1700$ \\
\hline TRAP33+ARB6 & 5 & $112-1570$ & TRAP40+ARB6 & 10 & $90-2000$ \\
\hline TRAP34+ARB1 & 7 & $200-1400$ & TRAP41+ARB1 & 9 & $130-1700$ \\
\hline TRAP34+ARB2 & 7 & $100-1100$ & TRAP41+ARB2 & 5 & $300-1400$ \\
\hline TRAP34+ARB3 & 2 & $150-500$ & TRAP41+ARB3 & 4 & $180-800$ \\
\hline TRAP34+ARB4 & 4 & $200-400$ & TRAP41+ARB4 & 4 & $120-1500$ \\
\hline TRAP34+ARB5 & 6 & $110-1400$ & TRAP41+ARB5 & 8 & $170-1400$ \\
\hline TRAP34+ARB6 & 8 & $150-1100$ & TRAP41+ARB6 & 9 & $110-1800$ \\
\hline TRAP35+ARB1 & 8 & $90-1800$ & TRAP42+ARB1 & 5 & $200-1500$ \\
\hline TRAP35+ARB2 & 10 & $130-1600$ & TRAP42+ARB2 & 8 & $180-1400$ \\
\hline TRAP35+ARB3 & 9 & $120-800$ & TRAP42+ARB3 & 9 & $110-1400$ \\
\hline TRAP35+ARB4 & 7 & $180-1500$ & TRAP42+ARB4 & 8 & $280-1400$ \\
\hline TRAP35+ARB5 & 6 & $100-780$ & TRAP42+ARB5 & 7 & $70-1500$ \\
\hline TRAP35+ARB6 & 6 & $60-450$ & TRAP42+ARB6 & 6 & $120-700$ \\
\hline TRAP43+ARB1 & 7 & $230-1300$ & TRAP50+ARB1 & 8 & $100-2072$ \\
\hline TRAP43+ARB2 & 7 & $120-1300$ & TRAP50+ARB2 & 7 & $80-1400$ \\
\hline TRAP43+ARB3 & 3 & $120-1300$ & TRAP50+ARB3 & 7 & $180-1400$ \\
\hline TRAP43+ARB4 & 4 & $180-1400$ & TRAP50+ARB4 & 8 & $60-1500$ \\
\hline
\end{tabular}

Continued on next page

Genetics and Molecular Research 16 (2): gmr16029647 


\begin{tabular}{|c|c|c|c|c|c|}
\hline Primers & Number of loci & Size of loci (bp) & Primers & Number of loci & Size of loci (bp) \\
\hline TRAP43+ARB5 & 5 & $180-2072$ & \begin{tabular}{|l} 
TRAP50+ARB5 \\
\end{tabular} & 7 & $120-1400$ \\
\hline TRAP43+ARB6 & 4 & $170-1000$ & TRAP50+ARB6 & 7 & $130-2072$ \\
\hline TRAP44+ARB1 & 7 & $180-1500$ & TRAP51+ARB1 & 10 & $180-1800$ \\
\hline TRAP44+ARB2 & 6 & $70-1000$ & TRAP51+ARB2 & 8 & $130-1700$ \\
\hline TRAP44+ARB3 & 9 & $110-1400$ & TRAP51+ARB3 & 6 & $90-1900$ \\
\hline TRAP44+ARB4 & 4 & $270-1800$ & TRAP51+ARB4 & 8 & $110-2000$ \\
\hline TRAP44+ARB5 & 10 & $90-1500$ & TRAP51+ARB5 & 9 & $90-2000$ \\
\hline TRAP44+ARB6 & 9 & $130-1500$ & TRAP51+ARB6 & 9 & $50-2000$ \\
\hline TRAP45+ARB1 & 6 & $300-2072$ & TRAP52+ARB1 & 7 & $50-2000$ \\
\hline TRAP45+ARB2 & 7 & $180-1800$ & TRAP52+ARB2 & 8 & $70-2072$ \\
\hline TRAP45+ARB3 & 8 & $180-2072$ & \begin{tabular}{|l|} 
TRAP52+ARB3 \\
\end{tabular} & 7 & $70-1400$ \\
\hline TRAP45+ARB4 & 5 & $280-900$ & TRAP52+ARB4 & 6 & $60-2072$ \\
\hline TRAP45+ARB5 & 7 & $150-1400$ & TRAP52+ARB5 & 5 & $60-1400$ \\
\hline TRAP45+ARB6 & 5 & $300-1000$ & TRAP52+ARB6 & 5 & $70-1900$ \\
\hline TRAP46+ARB1 & 10 & $60-2000$ & TRAP53+ARB1 & 9 & $180-1900$ \\
\hline TRAP46+ARB2 & 8 & $100-1900$ & TRAP53+ARB2 & 6 & $380-2000$ \\
\hline TRAP46+ARB3 & 9 & $80-1800$ & TRAP53+ARB3 & 8 & $160-1100$ \\
\hline TRAP46+ARB4 & 4 & $50-1400$ & TRAP53+ARB4 & 7 & $200-2000$ \\
\hline TRAP46+ARB5 & 13 & $50-2000$ & TRAP53+ARB5 & 8 & $120-1900$ \\
\hline TRAP46+ARB6 & 10 & $50-2000$ & TRAP53+ARB6 & 10 & $90-1800$ \\
\hline TRAP47+ARB1 & 7 & $110-1400$ & TRAP54+ARB1 & 3 & $180-1400$ \\
\hline TRAP47+ARB2 & 8 & $120-1600$ & TRAP54+ARB2 & 6 & $180-1300$ \\
\hline TRAP47+ARB3 & 4 & $130-1500$ & TRAP54+ARB3 & 6 & $120-1000$ \\
\hline TRAP47+ARB4 & 7 & $80-1500$ & TRAP54+ARB4 & 8 & $140-1400$ \\
\hline TRAP47+ARB5 & 9 & $200-900$ & TRAP54+ARB5 & 7 & $200-1000$ \\
\hline TRAP47+ARB6 & 7 & $170-2000$ & TRAP54+ARB6 & 7 & $110-1600$ \\
\hline TRAP48+ARB1 & 6 & $100-1100$ & TRAP55+ARB1 & 6 & $140-600$ \\
\hline TRAP48+ARB2 & 8 & $180-800$ & TRAP55+ARB2 & 8 & $120-800$ \\
\hline TRAP48+ARB3 & 6 & $80-2000$ & TRAP55+ARB3 & 6 & $100-1800$ \\
\hline TRAP48+ARB4 & 7 & $150-1500$ & TRAP55+ARB4 & 7 & $100-2000$ \\
\hline TRAP48+ARB5 & 6 & $180-1600$ & TRAP55+ARB5 & 10 & $90-1400$ \\
\hline TRAP48+ARB6 & 5 & $110-1000$ & TRAP55+ARB6 & 9 & $130-2000$ \\
\hline TRAP49+ARB1 & 6 & $50-2072$ & TRAP56+ARB1 & 8 & $90-1000$ \\
\hline TRAP49+ARB2 & 7 & $50-1500$ & TRAP56+ARB2 & 8 & $130-1200$ \\
\hline TRAP49+ARB3 & 7 & $200-2072$ & TRAP56+ARB3 & 11 & $90-1600$ \\
\hline TRAP49+ARB4 & 8 & $110-1200$ & TRAP56+ARB4 & 8 & $90-1500$ \\
\hline TRAP49+ARB5 & 9 & $100-1000$ & TRAP56+ARB5 & 11 & $120-2000$ \\
\hline TRAP49+ARB6 & 10 & $80-1900$ & TRAP56+ARB6 & 9 & $160-1300$ \\
\hline
\end{tabular}

Different results were obtained for sugarcane: an average of 33 fragments amplified based on 18 TRAP combinations, which varied between 100 and 700 bp (Alwala et al., 2006); and an average of 58 fragments with 16 TRAP combinations, which varied between 60 and $550 \mathrm{bp}$ (Suman et al., 2012). Also, for fava bean, Kwon et al. (2010) used 12 combinations of TRAP primers and found a variation of 7 to 37 fragments that had between 100 and $850 \mathrm{bp}$.

In general, the primers Arb5 and Arb6, in combination with the fixed primers, enabled the amplification of the greatest number of loci, which had an average of 8.0 and 7.9 loci per combination, respectively (Table 5).

Table 5. Arbitrary primers that enabled the amplification of the greatest number of loci in combination with fixed primers.

\begin{tabular}{l|c|c}
\hline \multirow{2}{*}{ Arbitrary primer } & No. of bands & \multicolumn{2}{c}{ Average } \\
\cline { 2 - 3 } & Total & 7.1 \\
\hline Arb 1 & 398 & 7.6 \\
\hline Arb 2 & 423 & 7.2 \\
\hline Arb 3 & 407 & 6.5 \\
\hline Arb 4 & 364 & 8.0 \\
\hline Arb 5 & 446 & 7.9 \\
\hline Arb 6 & 441 & \\
\hline
\end{tabular}

Genetics and Molecular Research 16 (2): gmr16029647 
Liu et al. (2005) reported the efficiency of TRAP markers. According to these authors, TRAP markers are very efficient at generating rapid markers throughout the genome of an organism and allow linkage groups to be determined and many gaps to be filled. TRAP markers have shown the same capacity as microsatellites to assign linkage groups to chromosomes.

For the primer Arb1, 5 of the analyzed combinations did not result in an amplification product, and for the primers Arb2, Arb3, Arb4, Arb5, and Arb6 the number combinations that did not amplify were $3,1,3,1$, and 2, respectively. The lack of amplification can be explained by the existence of genetic differences in the amplification target site of the original source used for sequencing in relation to the genotypes evaluated.

The TRAP markers developed and optimized in this study are the first functional markers developed for castor bean (based on a literature review). These markers constitute another important tool for genetic improvement programs and studies about genetic variability and population genetics of castor bean. In addition to the advantages mentioned, TRAP markers allow polymorphisms to be detected in regions near genes of interest in castor bean, which makes them useful in QTL identification and associative mapping studies because they accelerate the process of marker-assisted selection.

\section{Conflicts of interest}

The authors declare no conflict of interest.

\section{ACKNOWLEDGMENTS}

Research supported by Coordenação de Aperfeiçoamento de Pessoal de Nível Superior (CAPES), Petrobrás Biocombustível, and Agência Nacional de Petróleo, Gas Natural e Biocombustícel (ANP).

\section{REFERENCES}

Al-Doss AA, Elshafei AA, Moustafa KA, Saleh M, et al. (2011). Comparative analysis of diversity based on morphoagronomic traits and molecular markers in durum wheat under heat stress. Afr. J. Biotechnol. 10: 3671-3681 10.5897/AJB10.1993.

Alwala S, Suman A, Arro JA, Veremis JC, et al. (2006). Target region amplification polymorphism (TRAP) for assessing genetic diversity in sugarcane germplasm collections. Crop Sci. 46: 448-455 http://dx.doi.org/10.2135/ cropsci2005.0274.

Audi J, Belson M, Patel M, Schier J, et al. (2005). Ricin poisoning: a comprehensive review. JAMA 294: 2342-2351.

Bajay MM, Pinheiro JB, Nobrega MBM and Zucchi MI (2009). Development and characterization of microsatellite markers for castor (Ricinus communis L.), an important oleaginous species for biodiesel production. Conserv. Genet. Resour. 1: 237-239.

Bajay MM, Zucchi MI, Kiihl TAM, Batista CEA, et al. (2011). Development of a novel set of microsatellite markers for castor bean, Ricinus communis (Euphorbiaceae). Am. J. Bot. 98: 87-89.

Carmo CD, Santos DB, Alves LB, Oliveira GAF, et al. (2015). Development of TRAP (target region amplification polymorphism) as new tool for molecular genetic analysis in cassava. Plant Mol. Biol. Rep. 33: 1953-1966.

Chan AP, Crabtree J, Zhao Q, Lorenzi H, et al. (2010). Draft genome sequence of the oilseed species Ricinus communis. Nat. Biotechnol. 28: 951-956 http://dx.doi.org/10.1038/nbt.1674.

Costa MN, Pereira WE, Bruno RLA, Freire EC, et al. (2006). Divergência genética entre acessos e cultivares de mamoneira por meio de estatística multivariada. Pesq. Agropec. Bras. 4: 1617-1622.

Doyle JJ and Doyle JL (1990). A rapid total DNA preparation procedure for fresh plant tissue. Focus 12: 13-15.

Foster JT, Allan GJ, Chan AP, Rabinowicz PD, et al. (2010). Single nucleotide polymorphisms for assessing genetic diversity in castor bean (Ricinus communis). BMC Plant Biol. 10: 1-11.

Genetics and Molecular Research 16 (2): gmr16029647 
Gajera BB, Kumar N, Singh AS, Punvar BS, et al. (2010). Assessment of genetic diversity in castor (Ricinus communis L.) using RAPD and ISSR markers. Ind. Crops Prod. 32: 491-498 http://dx.doi.org/10.1016/j.indcrop.2010.06.021.

Gálová Z, Vivodík M, Balážová Z and Hlozáková TK (2015). Identification and differentiation of Ricinus communis L. using SSR markers. Potravinarstvo 9: 556-561 http://dx.doi.org/10.5219/516.

Goodarzi F, Darvishzadeh R and Hassani A (2015). Genetic analysis of castor (Ricinus communis L.) using ISSR markers. $J P M B$ 3: 18-34.

Hu J and Vick BA (2003). Target region amplification polymorphism: a novel marker technique for plant genotyping. Plant Mol. Biol. Rep. 21: 289-294.

Hu J, Ochoa OE, Truco MJ and Vick BA (2005). Application of the TRAP technique to lettuce (Lactuca sativa L.) genotyping. Euphytica 144: 225-235.

Kallamadi PR, Nadigatla VPRGR and Mulpuri S (2015). Molecular diversity in castor (Ricinus communis L.). Ind. Crops Prod. 66: 271-281 http://dx.doi.org/10.1016/j.indcrop.2014.12.061.

Kumar Y, Kwon SJ, Coyne CJ, Hu J, et al. (2014). Target region amplification polymorphism (TRAP) for assessing genetic diversity and marker-trait associations in chickpea (Cicer arietinum L.) germplasm. Genet. Resour. Crop Evol. 61: 965-977 http://dx.doi.org/10.1007/s10722-014-0089-2.

Kwon S, Hu J and Coyne CJ (2010). Genetic diversity and relationship among faba bean (Vicia faba L.) germplasm entries as revealed by TRAP markers. Plant Genet. Resour. 8: 204-213 http://dx.doi.org/10.1017/S1479262110000201.

Lakhani HN, Patel SV, Bodar NP and Golakiya BA (2015). RAPD analysis of genetic diversity of castor bean (Ricinus communis L.). Int. J. Curr. Microbiol. App. Sci. 4: 696-703.

Li G and Quiros CF (2001). Sequence-related amplified polymorphism (SRAP), a new marker system based on a simple PCR reaction: its application to mapping and gene tagging in Brassica. Theor. Appl. Genet. 103: 455-461 http:// dx.doi.org/10.1007/s001220100570.

Liu ZH, Anderson JA, Hu J, Friesen TL, et al. (2005). A wheat intervarietal genetic linkage map based on microsatellite and target region amplified polymorphism markers and its utility for detecting quantitative trait loci. Theor. Appl. Genet. 111: 782-794 http://dx.doi.org/10.1007/s00122-005-2064-y.

Luo C, Wu HX, Yao QS, Wang SB, et al. (2015). Development of EST-SSR and TRAP markers from transcriptome sequencing data of the mango. Genet. Mol. Res. 14: 7914-7919 http://dx.doi.org/10.4238/2015.July.14.17.

Machado EL and Silva AS (2013). Desenho e validação de iniciadores microssatélites SSR para mamoneira. Pesqui. Agropecu. Bras. 48: 1457-1463 http://dx.doi.org/10.1590/S0100-204X2013001100006.

Machado EL, Silva AS, Santos AS, Bastos LA, et al. (2013). Dissimilaridade genética entre cultivares de mamoneira por meio de marcadores RAPD. Pesq. Agropec.Bbras. 48: 342-345 http://dx.doi.org/10.1590/S0100-204X2013000300014.

Machado EL, Silva SA, Fernandes LS and Brasileiro HS (2016). Genetic variability and homozygosity in a F4 castor bean population by microsatellite markers. Bragantia 75: 307-313 http://dx.doi.org/10.1590/1678-4499.536.

Miklas P.N, Hu J, Grunwald NJ and Larsen KM (2006). Potential application of TRAP (Targeted Region Amplied Polymorphism) markers for mapping and tagging disease resistance traits in common bean. Crop Sci. 46: 910-916.

National Center for Biotechnology Information NCBI shotgun assembly sequences: Genome (WGS) and Transcriptome (TSA). Available at [http://www.ncbi.nlm.nih.gov/Traces/wgs/?val=AASG02]. Accessed January 1, 2016.

Pecina-Quintero V, Anaya-López JL, Núnez-Colín CA, Zamarripa-Colmenero A, et al. (2013). Assessing the genetic diversity of castor bean from Chiapas, México using SSR and AFLP markers. Ind. Crops Prod. 41: 134-143. http:// dx.doi.org/10.1016/j.indcrop.2012.04.033.

Premier Biosoft (2015). NetPrimer. Available at [http://www.premierbiosoft.com/netprimer]. Accessed January 1, 2016.

Rozen S and Skaletsky HJ (2000). Primer 3 on the www for general users and for biologist programmers. In: Bioinformatics methods and protocols: Methods in molecular biology (Krawetz S and Misener S, ed.). Humana Press, Totowa, 365-386.

Silva AS, Cerqueira LS, Vilarinhos AD, Amorim EP, et al. (2012). Variabilidade genética em cultivares de mamona por meio de marcadores RAPD. Magistra 24: 341-347.

Seo KI, Lee GA, Ma KH, Hyum DY, et al. (2011). Isolation and characterization of 28 polymorphic SSR loci from Castor Bean (Ricinus communis L.). J. Crop Sci. Biotech 14: 97-103 http://dx.doi.org/10.1007/s12892-010-0107-7.

Suman A, Ali K, Arro J, Parco AS, et al. (2012). Molecular Diversity Among Members of the Saccharum Complex Assessed Using TRAP Markers Based on Lignin-Related Genes. Bioenerg. Res 5: 197-205 http://dx.doi.org/10.1007/ s12155-011-9123-9.

Tan M, Yan M, Wang L, Yan X, et al. (2013). Replication of pistillate plants of Ricinus communis L. and investigation of the sex stability and genetic variation of the somaclones. Ind. Crops Prod. 50: 50-57 http://dx.doi.org/10.1016/j. indcrop.2013.06.042.

Tan M, Wu K, Wang L, Yan M, et al. (2014). Developing and characterising Ricinus communis SSR markers by data mining of whole-genome sequences. Mol. Breed. 34: 893-904 http://dx.doi.org/10.1007/s11032-014-0083-6.

Genetics and Molecular Research 16 (2): gmr16029647 
Tomar RS, Parakhia MV, Kavani RH, Dobariya KL, et al. (2014). Characterization of castor (Ricinus communis L.) genotypes using different markers. Res. J. Biotechnol. 9: 6-13.

Vivodík M, Balážová Ž and Gálová Z (2014). RAPD analysis of the genetic diversity of castor bean. Int. J. Biol. Vet. Agric. Food. Eng. 8: 648-651. http://dx.doi.org/ scholar.waset.org/1999.1/9998704.

Vivodík M, Balážová Z, Gálová Z and Hlozáková TK (2015). Evaluation of molecular diversity of new castor lines (Ricinus communis L.) using random amplified polymorphic DNA markers. Hortic. Biotechnol. Res. 1: 1-4.

Wang C, Li GR, Zhang ZY, Peng M, et al. (2013). Genetic diversity of castor bean (Ricinus communis L.) in Northeast China revealed by ISSR markers. Biochem. Syst. Ecol. 51: 301-307 http://dx.doi.org/10.1016/j.bse.2013.09.017.

Zhang JJ, Shu QY, Liu ZA, Ren HX, et al. (2012). Two EST-derived marker systems for cultivar identification in tree peony. Plant Cell Rep. 31: 299-310 http://dx.doi.org/10.1007/s00299-011-1164-1.

Genetics and Molecular Research 16 (2): gmr16029647 